\title{
ANALYSIS AND PREDICTION OF VIBRATIONS OF BALL BEARINGS CONTAMINATED BY OPEN PIT COAL MINE DEBRIS PARTICLES
}

\author{
Žarko Mišković, Radivoje Mitrović, Vesna Maksimović, Aleksandar Milivojević
}

Preliminary communication

Analysis of the relevant literature has shown that only few researches are dealing with the bearings dynamic behaviour in real environmental conditions where high concentration of solid contaminant particles is evident. There is still no established mathematical correlation between bearings vibration characteristics, working time and concentration level of contaminant particles in their grease. Solving this problem was the main goal of research described in this paper. First step was thorough analysis of the chemical composition and structure of contamination particles directly causing the sample bearings failure on open pit coal mines. After that, specific experimental methodology was developed and implemented. Finally, by processing of the experimental results, new mathematical correlation between listed bearings characteristics was determined.

Keywords: bearings; conveyor idlers; coal mines; contamination; particles; vibrations

\section{Analiza i predviđanje vibracija kotrljajnih kugličnih ležaja kontaminiranih nečistoćama s površinskih kopova uglja}

Prethodno priopćenje

Analiza relevantne literature pokazuje da se vrlo mali broj istraživača bavi problematikom dinamičkog ponašanja kotrljajnih ležaja u realnim eksploatacijskim uvjetima - gdje je evidentno prisustvo visoke koncentracije čvrstih čestica nečistoća. Još uvek nisu ustanovljene matematičke korelacije između vibracijskih karakteristika kotrljajnih ležaja, vremena koje su proveli u eksploatacijskim uvjetima i razine koncentracije čestica nečistoća u njihovom mazivu. Upravo je rješavanje ovog problema glavni cilj opisanog istraživanja. Prvi je korak u njegovoj realizaciji bila detaljna analiza kemijskog sastava i strukture čestica nečistoća koje direktno uzrokuju otkaze kotrljajnih ležaja sa površinskih kopova uglja. Nakon toga, razvijena je i implementirana specifična eksperimentalna metodologija za ispitivanje vibracijskih karakteristika odabranih uzoraka kotrljajnih ležaja. Konačno, statističkom obradom dobivenih eksperimentalnih rezultata, utvrđena je nova matematička korelacija između navedenih karakteristika kotrljajnih ležaja.

Ključne riječi: čestice; kontaminacija; kotrljajni ležaji; rudnici uglja; transportni valjci; vibracije

\section{Introduction}

Nowadays power industry worldwide is mainly based on fossil fuel processing and exploitation. However, lack of energy resources in nearby future is inevitable and that is why improvement of overall reliability and efficiency of power production systems is one of the main tasks of 21 st century science. It is determined by numerous researchers that very high percentage of energy losses in thermal power plants is caused by their transportation systems, especially by belt conveyors and their key elements - conveyor idlers [1-3].

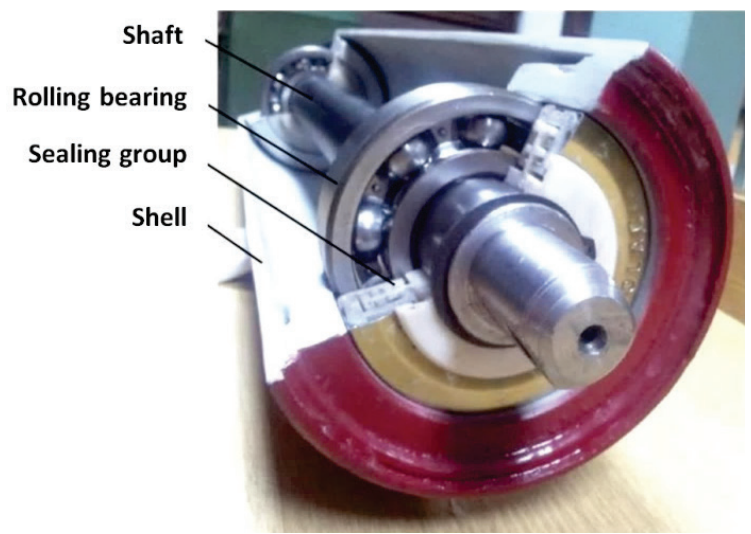

Figure 1 Component parts of typical conveyor idler assembly

Conveyor idlers (Fig. 1) are assemblies commonly consisting of shaft, shell, pair of sealing groups and pair of rolling bearings, with main purpose to provide support for conveyor belt and transported material. Taking into account that there are over 80000 conveyor idlers per standard open pit coal mine, it is clear that any improvement of its reliability leads to the significant improvement of power production systems overall performances.

Rolling bearings (usually ball bearings) are critical components of conveyor idlers. They are the most common reason for conveyor idlers failures on open pit coal mines [4-6]. If bearings are correctly installed and properly maintained, the time of their failure can be accurately predicted using modified equation of their basic life [7]:

$$
L_{n}=\left(\frac{Q_{c}}{Q}\right)^{p},
$$

Where: $L_{n}-$ Basic rating life ( $n$ - probability); $Q_{c}-$ Basic dynamic load; $Q$ - Actual load; $p$ - Constant.

Constant $p$ is a function of the three constants regarding maximum shear stress exponents, Weibull slope and bearing type. Different correlations of these constants were determined [8] but no matter the approach, constant $p$ has been approximated to the values 3 (ball bearings) and 10/3 (roller bearings).

The basic rating life $L 10$ is commonly used, calculating the expected service life which $90 \%$ of bearings of the same type will reach before failure. Also, the basic dynamic radial $C_{r}$ and axial $C_{a}$ load are used in conjunction with the dynamic equivalent radial $P_{r}$ or axial $P_{a}$ load [9].

Rating life $L 10$ is relevant for ideal working conditions, so it has to be improved by correction factors in order to predict bearings service life in working conditions. Those factors are described in detail in standard ISO 281:2007 which takes into account rolling 
bearing lubricating conditions, lubricant contamination level, operating temperature and fitting stresses:

$L_{n m}=a_{1} \times a_{I S O} \times L_{10}$

where: $L_{n m}-$ Modified rating life; $a_{1}$ - Life modification factor for reliability; $a_{I S O}-$ Life modification factor.

The life modification factor $a_{I S O}$ is calculated as:

$$
a_{I S O}=f\left(\frac{e_{c}, C_{u}}{P}, \kappa\right),
$$

where: $e_{c}-$ Contamination factor; $C_{u}-$ Fatigue load limit; $P$ - Dynamic equivalent load; $\kappa$ - Viscosity ratio of the lubricant.

According to the previous equations, it is clear that contamination can significantly affect rolling bearings service life, especially in case of conveyor idlers rolling bearings [4-6], because of very high concentration of solid contaminant particles in their working environment. The study of conveyor systems has shown that no matter how efficient the conveyor idlers sealing devices are, the environment conditions could be so varied and hostile that their bearings eventually become seriously damaged due to contamination by debris particles which have entered the bearings inner space [5].

Nowadays, in order to prevent premature bearing failure, there are several monitoring techniques in use such as oil analysis, wear debris analysis, vibration analysis and acoustic emission analysis [10, 11]. However, the vibration and the acoustic emission analysis are most frequently used because they provide complex information about the state of rolling bearings component parts $[12,13]$. According to Tomovic et al. the cause for vibration inducement in rolling bearings can be classified into four groups [14]:

1. Specific construction and operating profile of the rolling element bearing (primary bearing induced vibration - structural vibrations);

2. Bearing elements micro and macro geometry errors (vibrations of technological origin);

3. Bearing elements damage (vibrations due to damage of bearing elements);

4. Negative environmental impact (vibration due to the environmental effects).

When minor damages (due to fatigue, denting, scuffing, scoring, wear etc.) are present on rolling bearings contact surfaces, vibrations are increased as the motion of the rolling elements is more disturbed. The vibration signal can be then processed in time and frequency domain with statistical and arithmetical methods. However, data recorded in time domain could later be represented in the frequency domain by the use of a Fourier transformation (usually Discrete Time Fourier Transform (DTFT) by Fast Fourier Transform (FFT) algorithm). Also, vibration acceleration (usually expressed as the RMS value) is the most logical choice for consideration because it is most dominant vibration characteristic on high frequency ranges typical for rolling element bearings.
Despite numerous performed experiments and analysis there are still no mathematical models for contaminated bearings vibrations prediction. Solving this problem is the main goal of research presented in this paper: to establish a correlation between bearings vibrations characteristics change in time and concentration level of contamination particles in the grease of the bearings.

It is important to mention that in this particular research, working conditions for conveyor idler bearings from open pit coal mines were simulated but basic principles and presumptions are universal so they can be conditionally applied on any kind of rotating machinery. In addition to that, thorough analysis of real open coal mine debris particles was performed in order to find out the structure and origin of contaminant particles which cause the failure of rolling bearings in above mentioned working environment.

\section{Theoretical and experimental background}

According to the relevant literature, there are several possible mechanisms of rolling bearings wear due to contamination $[15,16]$. When hard particles go into the interference, surface damage by mechanisms such as denting is inevitable $[17,18]$. Dents essentially represent stress concentration sites, which increase the possibilities for the occurrence of spalling, accelerating the failure process [19]. In terms of contaminant particle sizes, Maru et al. [20] and Nikas et al. [21] state that the critical size of the contaminant particles is in the order of the lubrication film thickness. However, other authors claim that when particles larger than the oil film thickness enter the contact zone, they cause stress peaks and permanent indentations in the raceway as they are over rolled. These stress peaks lead to a reduced life of the rolling bearing due to fatigue [9].

Relation between grease contamination level and bearing vibrations is rather complex. The contact surface damage caused by contamination particles induces the bearings radial clearance change, significantly reducing its service life and increasing the overall vibrations level [22]. Also, load distribution between balls and rings of the rolling bearing is disturbed, which also affects the bearings vibrations level [23]. That is why selection of correct preload and number of bearing balls is very important as claimed by Tomovic [24] and Mitrovic [25]. Contact surface damage level also depends on the hardness of the ductile contamination particles and the strength of the brittle contamination particles, because they deform or fracture when they enter the zone between balls and rings of the contaminated bearing [26].

There are many experimental researches performed in order to determine precise relations between bearing contamination level and its vibrations. Maru et al. [20, 2729] presented works with a goal to study how contamination in the lubricant can affect vibrations, taking into account the effect of the contaminant particle size and its concentration level in the lubricant. In their experiments the oil of 6205 ball bearings (bore diameter: $25 \mathrm{~mm}$ ) was contaminated by standard quartz particles, with the average sizes of $37 \mu \mathrm{m}, 59 \mu \mathrm{m}$ and $111 \mu \mathrm{m}$. Also, three oil contamination levels were used, with 
nominal concentrations from $0,04 \mathrm{~g} / 1$ up to $0,7 \mathrm{~g} / \mathrm{l}$. The results have shown that it is possible to identify the presence of contamination from some specific frequency bands of the bearing vibration signal. Retesting of the rolling bearings with clean oil also revealed that some frequency bands are excited due to wear in the contacting elements.

Koulocheris et al. [9] performed experiments with three types of ball bearings (1207, 2207 and YSA - bore diameter: $35 \mathrm{~mm}$ ) whose grease was contaminated by hard corundum particles (alumina, Al2O3, hardness $2000 \mathrm{HV}$ ) with sizes of $62-73 \mu \mathrm{m}$ and $105-177 \mu \mathrm{m}$, where a quantity of $0,75 \mathrm{~cm}^{3}$ of particles were premixed with 50 $\mathrm{g}$ of clean SKF LGMT3 grease. Their goal was to find a pattern in the relationship between contamination particle sizes and wear progress, using vibrations analysis tools. The results have shown that wear is progressing faster when smaller particles are used. Similar experiment was performed by Lazovic et al. [17, 18] with standardized diamond dust as contamination material. Gained results were very similar and the influence of contamination on ball bearings internal radial clearance was also determined.

Mahajan and Utpat [30] investigate the trends in the amounts of vibration affected by contamination in the bearing grease and by the bearing wear itself. Experimental tests were performed on 6206-2RS deepgroove ball bearings (bore diameter: $30 \mathrm{~mm}$ ) and the Dolomite powder in three concentration levels $(5 \%, 15 \%$ and $25 \%$ of contaminant in $5 \mathrm{~g}$ of grease) and three different particle sizes $(53 \mu \mathrm{m}, 75 \mu \mathrm{m}$ and $106 \mu \mathrm{m})$.

The method of vibration analysis was effective in trends characterization in vibration due to solid contaminant in lubrication. The results have shown that, as the contaminant is added in the lubrication, there is a considerable increase in the vibration signatures of ball bearings. As the parameters like speed and load are varied, the acceleration values also vary, and as the particle size is increased the corresponding acceleration values are also increasing up to a certain limit, then they start to decrease.

It is clear from described experimental researches that particles used for artificial contamination were different depending on specific research approach and goal so they cannot accurately represent the contamination particles from exploitational working conditions of open pit coal mines conveyor idlers bearings. Also, rolling bearings used in conveyor idlers are much larger in size than those tested in described experiments. However, general conclusion could be made - there is a significant relation between rolling bearings vibrations and contamination, which leaves the space for further researches in this field, including mathematical models development of appropriate correlations.

\section{Starting assumptions}

Taking into account that per $1 \mathrm{~m}$ of open pit mine conveyor there are usually three linked idlers carrying the conveyor belt with transported material ('garland', Fig. 2 ), only the conditions of the middle one are simulated and aggravated by increased radial load and rotational speed - axial loads acting on the side conveyor idlers are fully neglected and it is presumed that middle idler takes
$70 \%$ of total load due to weight of belt and transported material [31, 32].

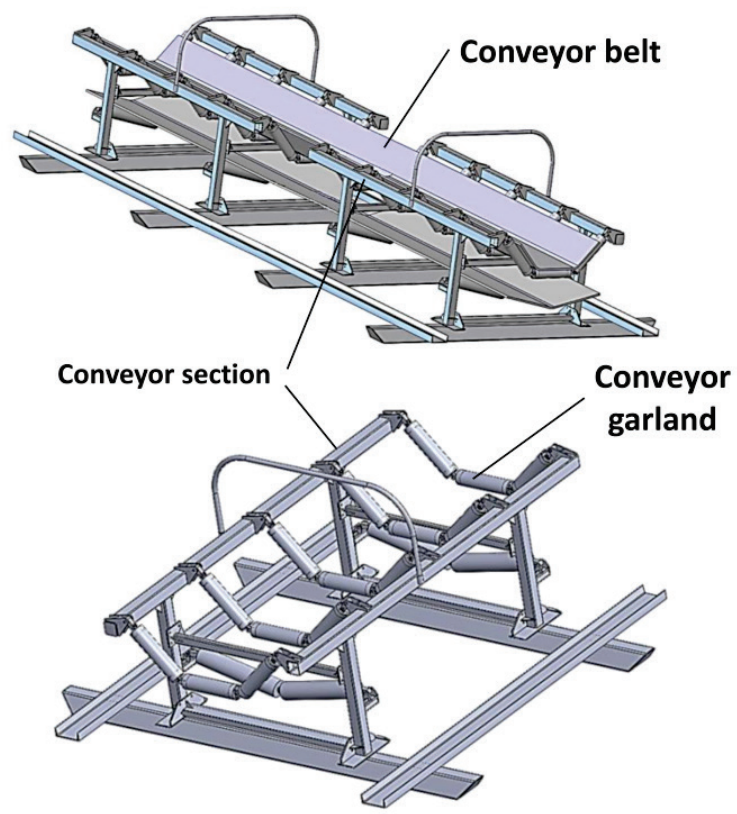

Figure 2 3D Model of typical open pit coal mine belt conveyor

In case of coal transportation, where transported material is lignite (density: $1,3 \mathrm{t} / \mathrm{m}^{3}$ ) and weight of $1 \mathrm{~m}$ of rubber belt is approximately $33 \mathrm{~kg}$, radial load acting on the middle conveyor idler equals $3,875 \mathrm{kN}$. If radial load due to conveyor idlers rotational parts mass is added ( $0,165 \mathrm{kN}$, obtained by standard 3D modelling software), it is calculated that exploitational radial load acting on each of the two conveyor idlers bearings in described conditions equals $\sim 2,0 \mathrm{kN}$. However, during the experimental research in this paper, experimental load applied on tested rolling bearings was $\sim 4,6 \mathrm{kN}$ in order to accelerate the bearings contact surface damage (it is important to mention that under this load bearing rings permitted angular deflection was not exceeded) .

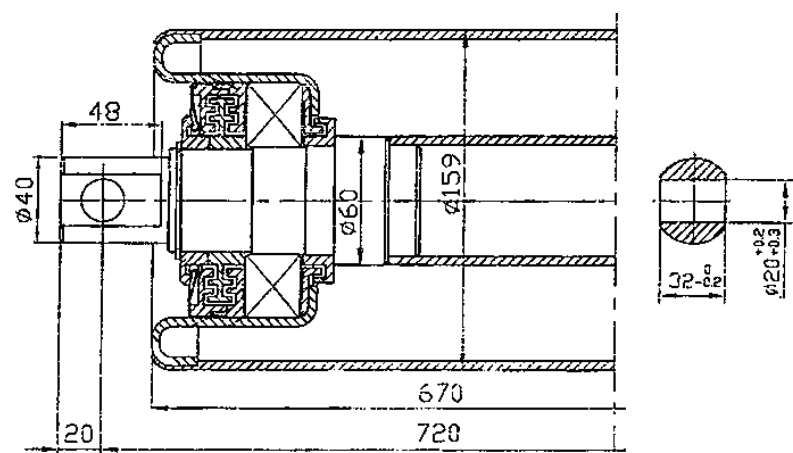

Figure 3 Technical drawing of conveyor idler assembly commonly used in the Republic of Serbia and Western Balkan region

The most common conveyor idlers used on open pit coal mines of the Republic of Serbia and Western Balkan region are those with outer diameters of $159 \mathrm{~mm}$ (Fig. 3) so their rolling bearings (usually, 6310-2Z/C3) are chosen to be experimentally tested. When the conveyor belt speed is $5 \mathrm{~m} / \mathrm{s}$, those idlers rotational speed equals approximately 600 RPM. Similar to the experimental radial load, in order to accelerate the damage of the tested conveyor idler bearings, applied experimental rotational 
speed $(\sim 1140$ RPM) was roughly two times larger than exploitational, which leads to the conclusion that acceleration of the performed experiments was $\sim 22,7 \mathrm{x}$. This means that $1 \mathrm{hr}$. of bearings work in experimental conditions corresponds to $22,7 \mathrm{hrs}$. of their work in exploitation - without contamination particles present [33].

Regarding the grease of the tested rolling bearings it is considered that mass of grease in the rolling bearing does not decrease during the exploitation and that contamination particles coming from the environment to the internal area of the bearing are evenly distributed in its grease.

The average amount of grease per $6310-2 \mathrm{Z} / \mathrm{C} 3$ bearing $(9,3 \mathrm{~g})$ is experimentally determined by weight measuring and averaging of the results from 70 tested samples and this value is used as the basis for further experiments. Also, as the standardised grease for precontamination, the SKF LGWA 2 grease was chosen because it is the commonly used grease for high loads and extreme pressures like those in conveyor idler bearings.

Despite the fact that chemical structure and origin of the contamination particles causing the failure of the rolling bearings from conveyor idlers on open pit coal mines were experimentally determined (as it will be described in one of the following chapters) they have to be normalised to be used as an artificial contaminant regarding their size so it is adopted that their size could not be larger than $120 \mu \mathrm{m}$ (similar to the other author's experiments described in Chapter 2) which is achieved by sieving with appropriate mechanical screens.

\subsection{Test samples}

The 6310-2Z/C3 rolling bearings were selected for testing because they are commonly used in conveyor idlers with outer diameters of $159 \mathrm{~mm}$. Basic characteristics of those bearings are presented in Tab. 1 and Fig. 4 [34] and all samples (70 in total) were measured, cleaned and measured again in order to determine the average weight of grease inside them.

Table 1 Main characteristics of $6310-2 Z / C 3$ bearings

\begin{tabular}{|c|c|c|c|c|c|c|}
\hline \multirow{2}{*}{\multicolumn{3}{|c|}{$\begin{array}{c}\text { Principal } \\
\text { dimensions }\end{array}$}} & \multicolumn{2}{|c|}{ Basic load rating } & \multicolumn{2}{|c|}{ Speed ratings } \\
\hline & & & \multirow{2}{*}{$\frac{\text { Dynamic }}{\mathrm{C}}$} & \multirow{2}{*}{$\frac{\text { Static }}{\mathrm{C}_{\mathrm{o}}}$} & \multirow{2}{*}{$\begin{array}{c}\text { Reference } \\
\text { speed }\end{array}$} & \multirow{2}{*}{$\begin{array}{c}\text { Limiting } \\
\text { speed }\end{array}$} \\
\hline $\mathrm{d}$ & $\mathrm{D}$ & $\mathrm{B}$ & & & & \\
\hline $\mathrm{mm}$ & $\mathrm{mm}$ & $\mathrm{mm}$ & $\mathrm{kN}$ & $\mathrm{kN}$ & $\mathrm{r} / \mathrm{min}$ & $\mathrm{r} / \mathrm{min}$ \\
\hline 50 & 110 & 27 & 62,4 & 38 & 15000 & 7800 \\
\hline
\end{tabular}
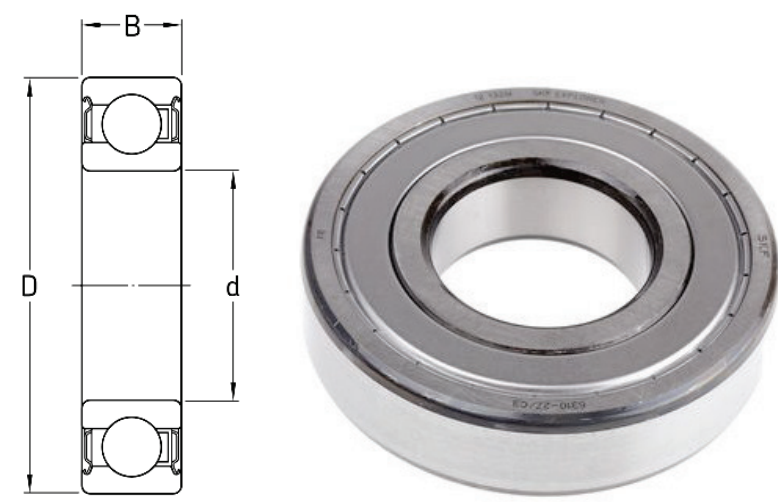

Figure 4 Designation and overall look of $6310-2 \mathrm{Z} / \mathrm{C} 3$ rolling bearings
Among those samples, 6 were chosen for further testing because their internal radial clearance was the same - $30 \mu \mathrm{m}$ (measured by accredited Laboratory for Machinery Elements and Systems Testing at the Faculty of Mechanical Engineering - University of Belgrade). That was important because, as described in Chapter 2, after a while the contamination increases the bearings internal radial clearance, thus affecting the overall level of bearings vibrations.

Selected bearings were then regreased with precontaminated SKF LGWA 2 grease and exposed to the previously determined experimental radial load and rotational speed (Chapter 3).

\subsection{Experimental contamination particles}

First step taken in order to gain contamination particles relevant for planned experiment was to take samples from open pit coal mine - it was concluded that there are three types of particles present: surface dust, excavation dirt and coal dust (Fig. 5-7).

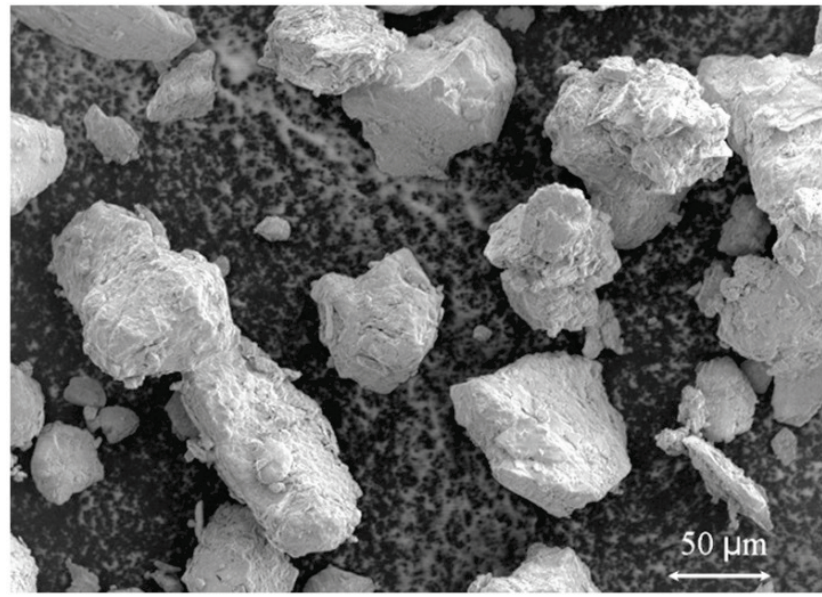

Figure 5 SEM image of the particles from open pit coal mine - surface dust

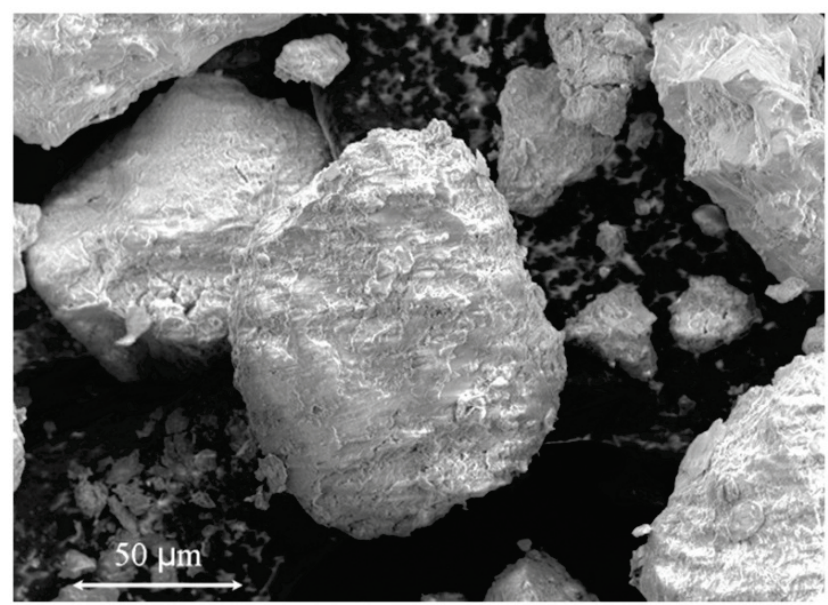

Figure 6 SEM image of the particles from open pit coal mine - excavation dirt

Samples from all three listed types of particles were taken and analysed regarding the size distribution and chemical composition. After that, fifteen failed conveyor idlers were taken from the open pit coal mine and disassembled. Contamination particles from their bearings were extracted, analysed and compared with the previous 
results, pointing out that typical cause of conveyor idler bearings failure was the excavation dirt (not the surface dust, as expected), mostly consisting of different kinds of quartz and fematite and magnetite (Fig. 8).

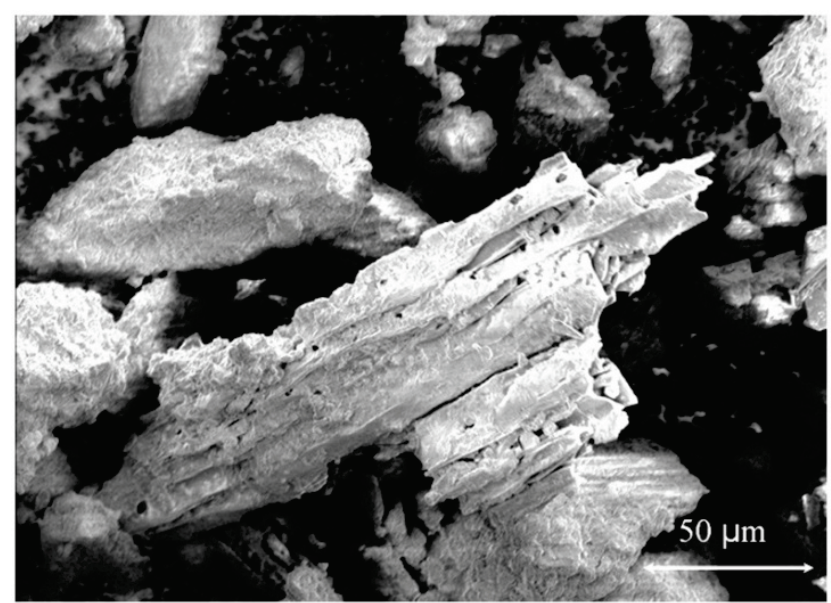

Figure 7 SEM image of the particles from open pit coal mine - coal dust

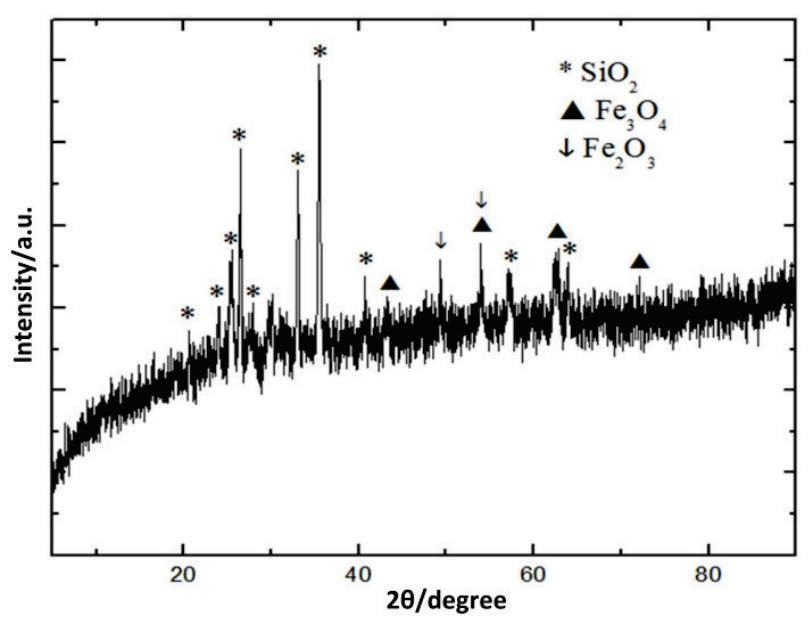

Figure 8 XRD analysis of contaminant particles - cause of conveyor idler's bearings failure on open pit coal mines

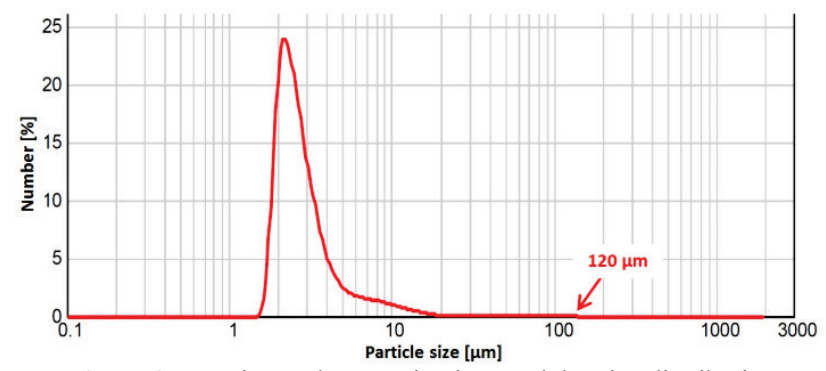

Figure 9 Experimental contamination particles size distribution

When the origin of conveyor idlers contamination particles was successfully determined, a sample for artificial bearing contamination was prepared by sieving excavation dirt with appropriate mechanical screen (mesh size less than $120 \mu \mathrm{m}$ ) - gained particle size distribution is shown in Fig. 9 (Horizontal axis - Particle size in $\mu \mathrm{m}$, Vertical axis $-\%$ of particles of certain size).

\subsection{Precontaminated grease characteristics}

Because of its high endurance and temperature resistance, as well as widespread usage, the SKF LGWA
2 grease was chosen for pre-contamination. Basic characteristics of mentioned grease are presented in Tab. 2 [35].

Table 2 Basic characteristics of SKF LGWA 2 grease

\begin{tabular}{|c|c|}
\hline DESIGNATION & SKF LGWA 2 \\
\hline DIN 51825 code & KP2N-30 \\
\hline NLGI consistency class & 2 \\
\hline Soap type & Lithium complex \\
\hline Base oil type & Mineral \\
\hline Operating temperature range & $\begin{array}{l}-30 \text { to }+140{ }^{\circ} \mathrm{C} \\
\left(-20 \text { to }+285{ }^{\circ} \mathrm{F}\right)\end{array}$ \\
\hline \multicolumn{2}{|c|}{ Dropping point DIN ISO 2176} \\
\hline Base oil viscosity & 185 \\
\hline $40^{\circ} \mathrm{C}, \mathrm{mm}^{2} / \mathrm{s}$ & 15 \\
\hline $100^{\circ} \mathrm{C}, \mathrm{mmVs}$ & \\
\hline
\end{tabular}

In total, three samples of pre-contaminated grease were prepared:

1. Clean grease (in packages of $9,3 \mathrm{~g}$ );

2. Grease with $10,75 \%$ of contaminant particles (in packages of $9,3 \mathrm{~g}$ of clean grease $+1 \mathrm{~g}$ of contaminant particles);

3. Grease with $21,5 \%$ of contaminant particles (in packages of $9,3 \mathrm{~g}$ of clean grease $+2 \mathrm{~g}$ of contaminant particles).

During the sample preparation, METRON (Germany) scales with precision of $0,001 \mathrm{~g}$ were used. However, estimated uncertainty of measurement was much higher approximately $0,1 \mathrm{~g}$. The primary cause of this uncertainty was the fact that grease gets stacked on the walls of containing vessels during the measuring and manipulation.

\subsection{Testing equipment}

For applying of the predetermined bearings radial load and rotational speed the custom made test frame, developed at the University of Belgrade - Faculty of Mechanical Engineering, was used (Fig. 10). Its working principle is shown in Fig. 11.

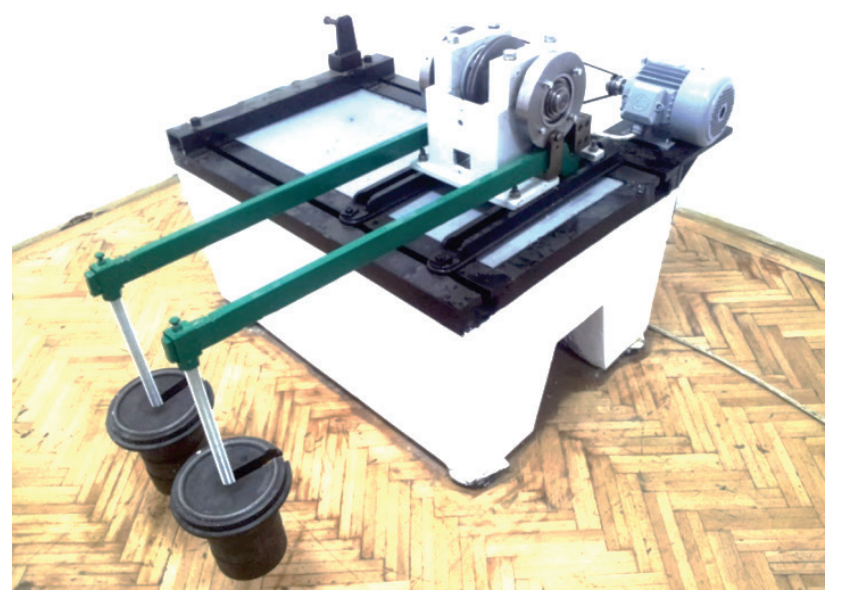

Figure 10 Rolling bearings test frame developed at the University of Belgrade - Faculty of Mechanical Engineering

Different radial loads were generated by levers with appropriate weights and different bearing rotational speeds by belt pulleys change. 


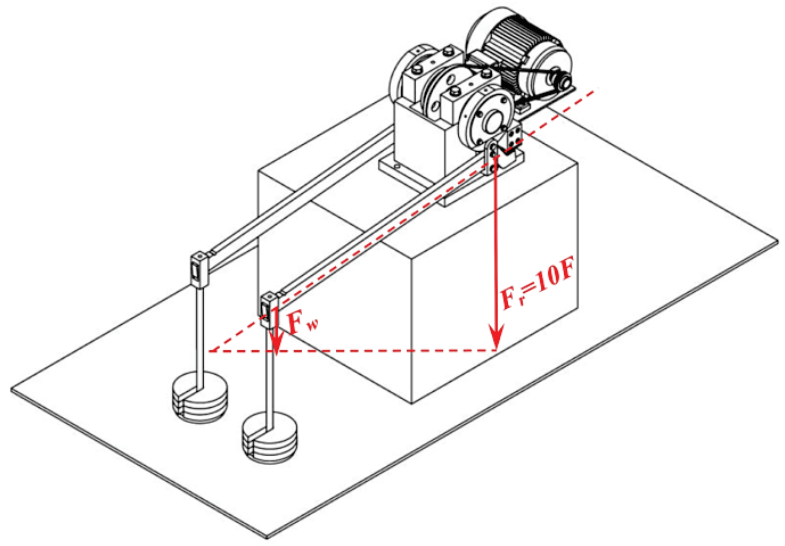

Figure 11 Working principle of rolling bearings test frame developed at the University of Belgrade - Faculty of Mechanical Engineering

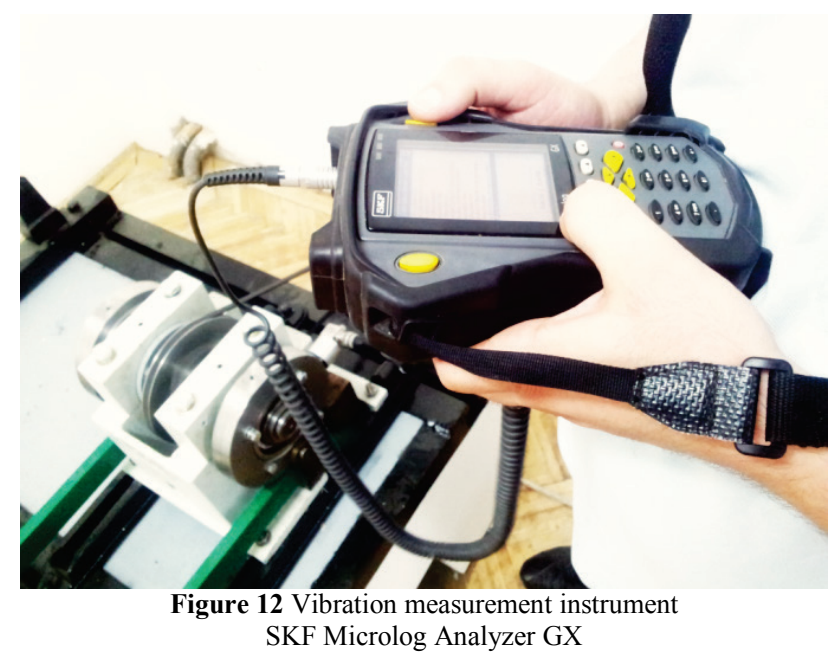

Bearings vibrations level measurements were performed by standard vibration measuring instrument SKF Microlog Analyzer GX with appropriate accelerometers (vibration sensors) - Fig 12.

During the testing, vibration sensors were placed to measure bearings acceleration in vertical radial direction and fixed by adequate threads (Fig. 13).

\subsection{Testing procedure}

All six selected samples $(6310-2 \mathrm{Z} / \mathrm{C} 3$ ball bearings with internal radial clearance of $30 \mu \mathrm{m}$ ) were tested in pairs on two test frames measuring places, according to the following procedure:

1. First pair of samples was greased by $9,3 \mathrm{~g}$ of clean grease per sample;

2. Second pair of samples was greased by $9,3 \mathrm{~g}$ of grease contaminated by $1 \mathrm{~g}$ of prepared particles per sample;

3. Third pair of samples was greased by $9,3 \mathrm{~g}$ of grease contaminated by $2 \mathrm{~g}$ of prepared particles per sample;

4. First pair of samples was mounted on the test frame and exposed to radial load of $4,6 \mathrm{kN}$ and rotational speed of 1140 RPM;

5. Every half hour samples radial vibrations acceleration expressed as the RMS value was recorded (Fig. 7);

6. After $10 \mathrm{hrs}$. of testing experiment was finished and sample bearings were dismounted from the test frame;
7. Second pair of samples was mounted on the test frame and exposed to radial load of $4,6 \mathrm{kN}$ and rotational speed of 1140 RPM;

8. Every half hour samples radial vibrations acceleration expressed as the RMS value was recorded;

9. After $10 \mathrm{hrs}$. of testing the experiment was finished and sample bearings were dismounted from the test frame;

10. Third pair of samples was mounted on the test frame and exposed to radial load of $4,6 \mathrm{kN}$ and rotational speed of 1140 RPM;

11. Every half hour samples radial vibrations acceleration expressed as the RMS value was recorded;

12. After $10 \mathrm{hrs}$. of testing experiment was finished and sample bearings were dismounted from the test frame.

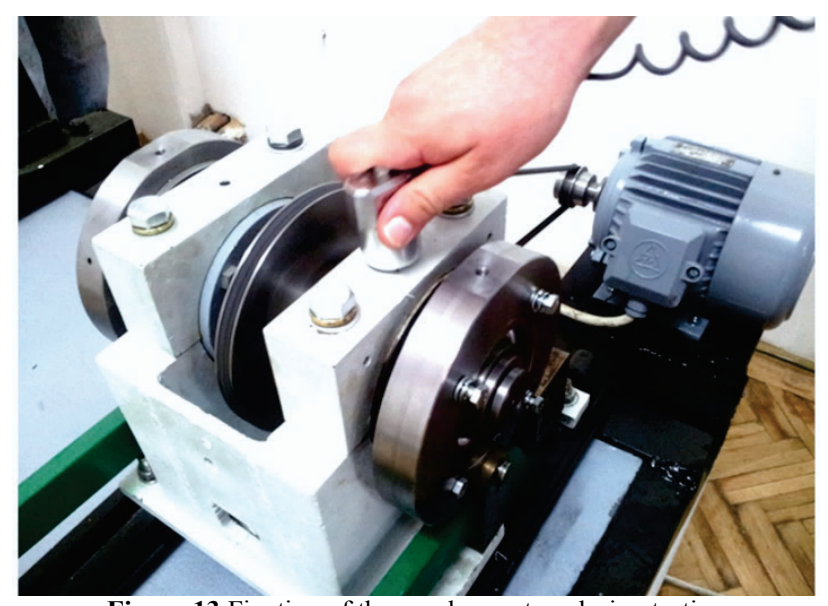

Figure 13 Fixation of the accelerometers during testing
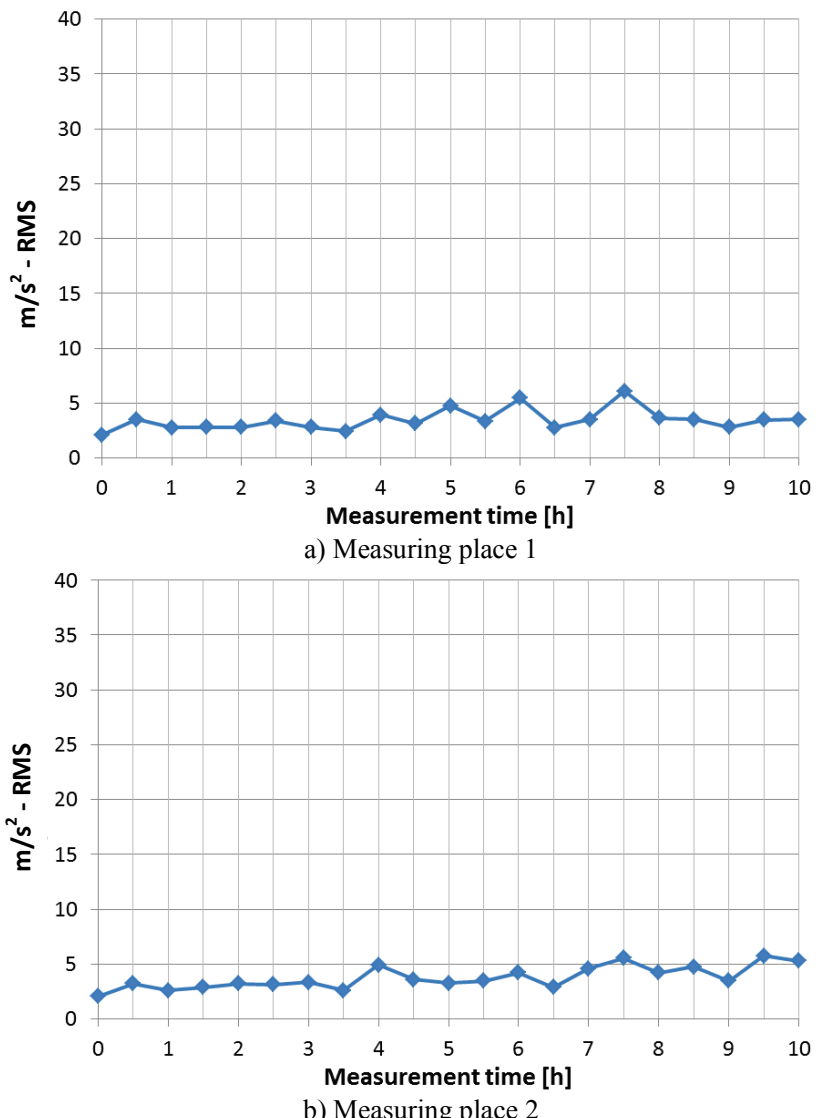

Figure 14 Bearings radial vibrations expressed as the RMS value of samples greased by SKF LGWA 2 clean grease 


\section{Results}

In Figs. 14-16, the diagrams with recorded bearings radial vibrations (expressed as the RMS value) are presented.
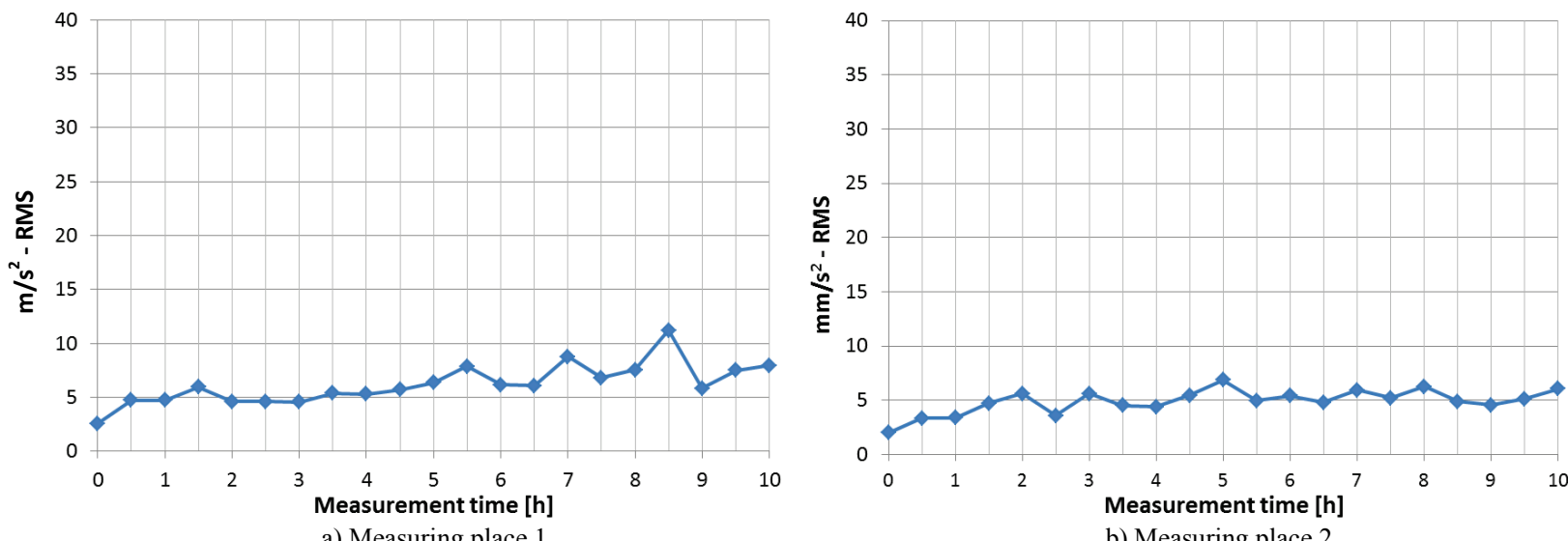

Figure 15 Bearings radial vibrations expressed as the RMS value of samples greased by SKF LGWA 2 grease with 10,75\% of contamination particles
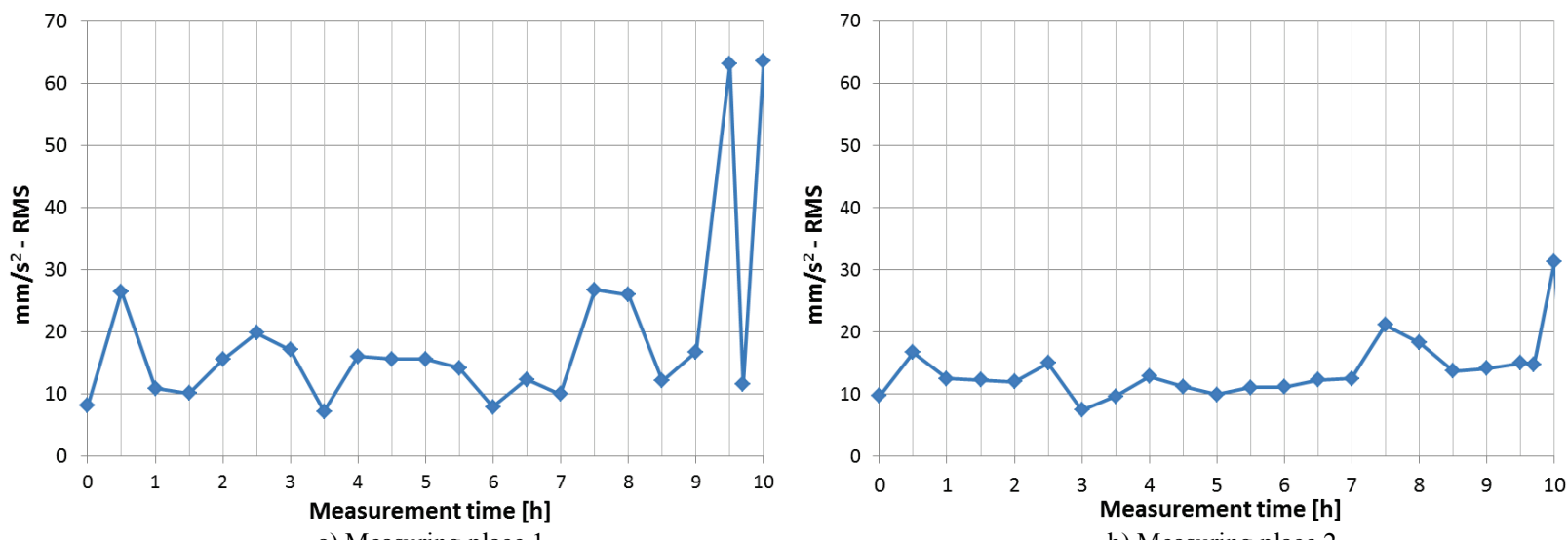

a) Measuring place

b) Measuring place 2

Figure 16 Bearings radial vibrations expressed as the RMS value of samples greased by SKF LGWA 2 grease with 21,5\% of contamination particles

\section{Generated mathematical model}

Using software for statistical analysis and data interpolation, over 200 different interpolation models were implemented on measured experimental values, and the most relevant regarding its statistical significance was:

$y=a+b \times x_{1}+c \times x_{2}+d \times x_{1}^{2}+e \times x_{2}^{2}+f \times x_{1} \times x_{2}$

Where: $y$ - bearings radial vibrations intensity expressed as the RMS value $\left(\mathrm{mm} / \mathrm{s}^{2}\right) ; x_{1}-$ time $(\mathrm{s}) ; x_{2}-$ mass of added particles per $9,3 \mathrm{~g}$ of clean grease; $a, b, c, d, e, f-$ coefficients depending on experimental conditions.

Graphical presentation of generated correlation for experimental conditions described in Chapter 5 is shown in Fig. 17.

Residual plot (errors) of all measured vibrations intensities, expressed as RMS values, is graphically presented in Fig. 18.

It is important to mention that coefficient of multiple determination $\left(R^{2}\right)$ for correlation presented in Fig. 17 equals 0,531 and its adjusted coefficient of multiple determination $\left(R a^{2}\right)$ is 0,512 - which are the highest gained values for all implemented interpolation models.

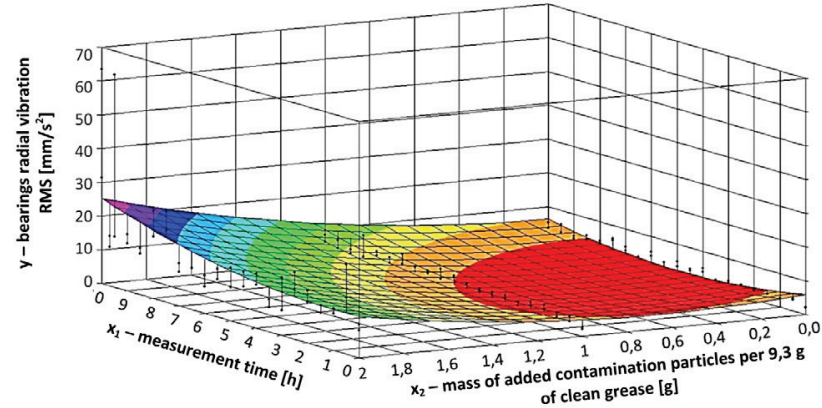

Figure 17 Graphical presentation of interpolated measured bearings radial vibrations expressed as the RMS

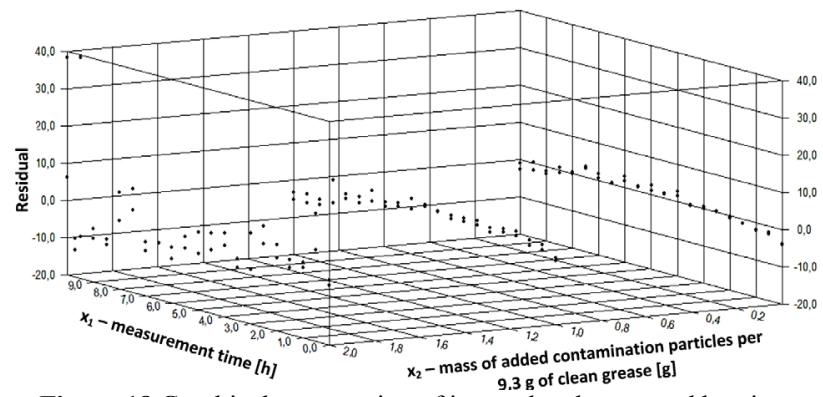

Figure 18 Graphical presentation of interpolated measured bearings radial vibrations expressed as the RMS 
Coefficients $a, b, c, d, e$ and $f$ (from the equation No. 4) depend on demanded confidence intervals and their values for described specific experimental conditions are shown in Tab. 3.

Table 3 Values of coefficients $a, b, c, d, e$ and $f$ for different confidence intervals

\begin{tabular}{|c|c|c|c|c|}
\hline Variable & Value & $(+/-)$ & Lower Limit & Upper Limit \\
\hline \multicolumn{5}{|c|}{$90 \%$ Confidence Interval } \\
\hline$a$ & 5,996126 & 3,373442 & 2,622683 & 9,369568 \\
\hline$b$ & $-1,558572$ & 1,207329 & $-2,765901$ & $-0,351243$ \\
\hline$c$ & $-5,606899$ & 4,452887 & $-10,059786$ & $-1,154011$ \\
\hline$d$ & 0,158217 & 0,11121 & 0,047007 & 0,269427 \\
\hline$e$ & 4,380776 & 1,954214 & 2,426562 & 6,334989 \\
\hline$f$ & 0,633565 & 0,36473 & 0,268835 & 0,998295 \\
\hline \multicolumn{7}{|c|}{$95 \%$ Confidence Interval } \\
\hline a & 5,996126 & 4,029242 & 1,966883 & 10,025368 \\
\hline $\mathrm{b}$ & $-1,558572$ & 1,442035 & $-3,000607$ & $-0,116537$ \\
\hline $\mathrm{c}$ & $-5,606899$ & 5,318533 & $-10,925432$ & $-0,288366$ \\
\hline $\mathrm{d}$ & 0,158217 & 0,132829 & 0,025388 & 0,291046 \\
\hline $\mathrm{e}$ & 4,380776 & 2,334114 & 2,046661 & 6,714890 \\
\hline $\mathrm{f}$ & 0,633565 & 0,435633 & 0,197932 & 1,069199 \\
\hline
\end{tabular}

\section{Results discussion}

Analysis of the results presented in Figs. 14-18, have shown that there is a peak of bearings vibration at the beginning of their work, which is in accordance with the theory that contamination particles larger than the bearings grease film thickness are at first mechanically crushed, directly inducing initial vibration level increment. Later, when contamination particles are smaller in size, bearings radial vibrations levels slowly grow until they reach the certain value when their intensity rapidly rises in time. That moment could be conditionally taken as the beginning of failure.

It is also interesting to notice that bearings vibrations levels and their measured maximal values are very consistent - bearings tested in the same experimental conditions have shown almost identical dynamic behaviour.

Regarding the generated interpolation equation of the experimentally measured values, it could be considered that gained $R^{2}$ and $R a^{2}$ are relatively high $(>0,5)$, which leads to the conclusion that it represents measured values with rather reasonable accuracy. If the gained $\mathrm{R}^{2}$ and $\mathrm{Ra}^{2}$ values were too low that could be a sign that interpolation model was not statistically good (not necessary, according to some authors [36]). Additionally, residual probability of determined correlation does not oscillate around a straight line, which could be also interpreted as a sign that regression model is well chosen.

\section{Conclusion}

In this paper the correlation between bearings vibration characteristics, their working time and concentration level of exploitational contamination particles in their grease for specific working conditions of open pit coal mine conveyor idlers was presented.

Developed mathematical model was generated by accurate software for statistical analysis and data interpolation with rather high gained values of coefficient of multiple determination and adjusted coefficient of multiple determination - which confirmed the validity of developed equation. At the moment the presented correlation model is unique, regardless of the total number of tested bearing samples (among 70 tested bearings only 6 happened to have equal internal radial clearances) - so it could be successfully used as a basis for further researches.

For example, contamination factor $e_{c}$ (from standard ISO 281:2007 and equation for life modification factor $a_{I S O}$ ) could be additionally improved, especially regarding the way it is adopted nowadays - still by descriptive contamination grades presented in Tab. 4 [37], despite the fact that quantitative means are far more accurate.

Table 4 Contamination factor $\mathrm{e}_{\mathrm{c}}$ (standard ISO 281:2007)

\begin{tabular}{|l|c|c|}
\hline \multirow{2}{*}{\multicolumn{1}{c|}{$\begin{array}{c}\text { Grade of } \\
\text { Contaminations }\end{array}$}} & \multicolumn{2}{|c|}{ Lubricant Contamination Factor $e_{c}$} \\
\cline { 2 - 3 } & DPW $<100$ & DPW $\geq 100$ \\
\hline Extreme Cleanliness & 1 & 1 \\
\hline High Cleanliness & 0,8 to 0,6 & 0,9 to 0,8 \\
\hline Standard Cleanliness & 0,6 to 0,5 & 0,8 to 0.6 \\
\hline Slight Contaminations & 0,5 to 0,3 & 0,6 to 0,4 \\
\hline Typical Contaminations & 0,3 to 0,1 & 0,4 to 0,2 \\
\hline Strong Contaminations & 0,1 to 0,0 & 0,1 to 0 \\
\hline Very Strong & 0 & 0 \\
\hline
\end{tabular}

Additionally, the developed testing methodology could be used for qualitative assessment of rolling bearings produced by different manufacturers, new and repaired rolling bearings, rolling bearings of different types etc. indirectly increasing the overall quality of matching conveyor idlers and other rotating machines. Precisely determined bearing service life can provide the most effective preventive maintenance of conveyor idlers according to the JIT principle ('Just in Time'), avoiding losses due to unplanned standstills and emergency maintenance.

Importance of developed methodology also lies in the fact that it could be potentially used for improvement of existing bearings state monitoring techniques - by setting the new reference bearings vibrations values, appropriate for comparison with the vibrations measured in real working conditions.

Bearing in mind previous observations, future experimental researches are already planned. Within them, the following variables will be varied:

1. Quantity of the bearings' grease;

2. Types of tested bearings;

3. Mass and size of added contamination particles;

4. Applied radial loads and rotational speeds.

\section{Acknowledgements}

Research presented in this paper was realised in period 2013-2015, within Project TR35029, so authors would like to express their sincere gratitude for material and financial support to the Ministry of Education, Science and Technological Development of the Republic of Serbia, as well as to the thermal power plant 'Termoelektrane i Kopovi Kostolac d.o.o.'.

\section{References}

[1] Antoniak, J. Theoretical basis and industrial applications of energy - saving and increased durability belt conveyor. // Acta Montanistica Slovaca. 8, 2-3(2003); pp. 150-157. 
[2] Antoniak, J. Resistances to the motion in mining belt conveyors. // Acta Montanistica Slovaca. 6, 2(2001), pp. 150-157.

[3] Gładysiewicz, L.; Król, R.; Bukowski, J. Tests of belt conveyor resistance to motion. // Maintenance and Reliability. 3(2011), pp. 17-25.

[4] Madden, W.F. An investigation into idler seals and the effect on rim drag. // The Key Center for Bulk Solids and Particular Technologies, Beltcon, The Web version (1997), http://www.saimh.co.za/beltcon/beltcon9/paper918.html. $(28.11 .2015)$

[5] Stewart-Lord, M. Rolling bearing characteristics required for maximising the life of conveyor idler rolls. // Beltcon, The Web version (1991), 6, http://www.saimh.co.za/ beltcon/beltcon6/paper66.html . (28.11.2015)

[6] Inpro/Seal Company Rock Island, IL, http://www.mtonline.com/january2007/problem-solvers-conveyor-idlerbearing-isolator-increases-reliability-and-safety-whilereducing-downtime-and-power-consumption (28.11.2015)

[7] Palmgren, A.; Lundberg, G. Dynamic capacity of rolling bearings. // Acta Polytechnica. 1(1947); pp. 3-7.

[8] Harris, T.; Kotzalas, M. Advanced concepts of bearing technology. 5th ed., Boca Raton: CRC Press, USA, 2007.

[9] Koulocheris, D.; Stathis, A.; Costopoulos, Th. et al. Comparative study of the impact of corundum particle contaminants size on wear and fatigue life of grease lubricated ball bearings. // Modern Mechanical Engineering. 3(2013), pp. 161-170. https://doi.org/10.4236/mme.2013.34023

[10] Bakić, G.; Đukić, M.; Lazović, T. et al. New methodology for monitoring and prevention of rotating parts failures. // FME Transactions. 35(2007), pp. 195-200.

[11] Subić, A.; Mitrović, R. A general aproach to rolling bearing analysis. // FME Transactions. 2(1992), pp. 7-10.

[12] Manjunath, A.; Girish, D.V. D0efect detection in deep groove polymer ball bearing using vibration analysis. // International Journal of Recent advances in Mechanical Engineering (IJMECH). 2/3(2013), pp. 45-52.

[13] Plavšić, N.; Lazović, T.; Stamenić, Z. Vibration diagnostic of rolling-bearings. // Proceedings of Conf. IRMES 2002 / Jahorina, 2002, pp. 577-582.

[14] Tomović, R.; Miltenović, V.; Banić, M.; Miltenović, A. Vibration response of rigid rotor in unloaded rolling element bearing. // International Journal of Mechanical Sciences. 52(2010), pp. 1176-1185. https://doi.org/10.1016/j.jimecsci.2010.05.003

[15] Godet, M. The third body aproach: a mechanical view of wear. // Wear. 100, 1-3(1984), pp. 437-452.

[16] Nikas, G. K. A state-of-the-art review on the effects particulate contamination and related topics in machineelement contacts. // IMECH Eng J-J Eng Tr. 224, 5(2010), pp. 453-479. https://doi.org/10.1243/13506501JET752

[17] Lazović, T.; Mitrović, R.; Ristivojević, M. Influence of abrasive particles geometry and material properties on the type of abrasive wear. // Proceedings of 8th International Tribology Conference - ITC '03 / Belgrade, 2003, pp. 8386.

[18] Lazović, T.; Mitrović, R.; Marinković, A. Influence of abrasive wear on the ball bearing service life. // Proceedings of 2nd European Conference on Tribology ECOTRIB 2009 / Pisa, 2009, pp. 387-392.

[19] Singotiaa, G.; Jainb, A. K. Experimental study of various solid contamination in ball bearings. // International Journal of Emerging Trends in Engineering and Development. 5, 3(2013), pp. 15-21.

[20] Maru, M. M.; Castillo, R. S.; Padove, L. R. Solid contamination in ball bearings through vibration and wear analyses. // Trib. International. 40, 3(2007), pp. 433-440. https://doi.org/10.1016/j.triboint.2006.04.007
[21] Nikas, G. K.; Sayles, R. S.; Ioannides, E. Effects of debris particles in sliding/rolling elastohydro dynamic contacts. // IMECH Eng J-J Eng Tr. 212, 5(1998), pp. 333-342.

[22] Lazović, T.; Mitrović, R.; Ristivojević, M. Influence of internal radial clearance on the ball bearing service life. // Journal of the Balkan Tribological Association. 16(2010), pp. 1-8.

[23] Tomović, R. Calculation of the necessary level of external radial load for inner ring support on q rolling elements in a radial bearing with internal radial clearance. // International Journal of Mechanical Sciences. 60, 2012, pp. 23-33. https://doi.org/10.1016/j.jimecsci.2012.04.002

[24] Tomović, R. Calculation of the boundary values of rolling bearing deflection in relation to the number of active rolling elements. // Mechanism and Machine Theory. 47, (2012), pp. $74-88$ https://doi.org/10.1016/i.mechmachtheory.2011.08.006

[25] Mitrović, R. Study on influence of design and tribology parameters on rolling bearings working performances during high speed rotations. // $\mathrm{PhD}$ Thesis, University of Belgrade, Serbia, 1992.

[26] Dwyer-Joyce, R. S. Predicting the abrasive wear of ball bearings by lubricant debris. // Wear. 233-235(1999), pp. 692-701. https://doi.org/10.1016/S0043-1648(99)00184-2

[27] Maru, M. M.; Serrato-Castillo, R.; Padovese, L. R. Influence of oil contamination on vibration and wear in ball and roller bearings. // Industrial Lubrication and Tribology. 59, 3(2007), pp. 137-142. https://doi.org/10.1108/00368790710746101

[28] Maru, M. M.; Serrato-Castillo, R.; Padovese, L. R. Effect of the presence of solid contamination and the resulting wear on the mechanical signature of ball bearings. // Proceedings of 18th International Congress of Mechanical Engineering / Ouro Preto, 2005, pp. 1-6.

[29] Maru, M. M.; Serrato-Castillo, R.; Padovese, L. R. Detection of solid contamination in rolling bearing operation through mechanical signature analysis. // Procceedings of 12th International Congress on Sound and Vibration / Lisbon, 2005, pp. 1-8

[30] Mahajan, O. L.; Utpat, A. A. Study of effect of solid contaminants in the lubricant on ball bearings vibration. // International Journal of Instrumentation, Control and Automation (IJICA). 1(2012), pp. 112-115.

[31] Group of authors, Belt Conveyors for Bulk Materials. 7th ed. CEMA - Conveyor Equipment Manufacturers Association, USA, 2014.

[32] Ayres de Silva, L. A.; Chaves, A. P.; Hennies, W. T. Mine Planning and Equipment Selection. CRC Press, Boca Raton, USA, 1996

[33] Gładysiewicz, L.; Król. R. Kompleksowa ocena jakości krążników poliuretanowych stosowanych w górnictwie oodkrywkowym. // Studia i Materiały, Prace Naukowe Instytutu Górnictwa Politechniki Wrocławskiej, 36, 128(2009), pp. 19-30.

[34] Deep groove ball bearings, single row, http://www.skf.com/ group/products/bearings-units-housings/ball-bearings/deepgroove-ball-bearings/single-row-deep-groove-ballbearings/single-row-skf-energy-efficient-e2-bearings/ index.html. (28.11.2015)

[35] High load, extreme pressure, wide temperature range grease, http://www.skf.com/group/products/lubricationsolutions/lubricants/high-load-extreme-pressure-widetemperature-range-grease/index.html. (28.11.2015)

[36] Regression Analysis. http://blog.minitab.com/blog/ adventures-in-statistics/regression-analysis-how-do-iinterpret-r-squared-and-assess-the-goodness-of-fit. (28.11.2015)

[37] Modified Rating Life. Bearing http://www.cwbearing.com/mod ratinglife.html. (28.11.2015) 


\section{Authors' addresses}

Žarko Mišković, M.Sc.

University of Belgrade, Faculty of Mechanical Engineering

Kraljice Marije 16, 11120 Belgrade 35, Serbia

E-mail: zmiskovic@mas.bg.ac.rs

Radivoje Mitrović, Ph.D.

University of Belgrade, Faculty of Mechanical Engineering

Kraljice Marije 16, 11120 Belgrade 35, Serbia

E-mail: rmitrovic@mas.bg.ac.rs

Vesna Maksimović, Ph.D.

University of Belgrade, Vinča Institute of nuclear sciences

PO Box 522, 11001 Belgrade, Serbia

E-mail: vesnam@vinca.rs

Aleksandar Milivojević, Ph.D.

University of Belgrade, Faculty of Mechanical Engineering

Kraljice Marije 16, 11120 Belgrade 35, Serbia

E-mail:amilivojevic@mas.bg.ac.rs 